\title{
The measurement of liquid and solid digesta retention in ruminants, equines and rabbits given timothy (Phleum pratense) hay
}

\author{
BY PETER UDÉN*, T. R. ROUNSAVILLE, G. R. WIGGANS \\ AND P. J. VAN SOEST \\ Department of Animal Science, Cornell University, Ithaca, NY, USA
}

(Received 12 June 1981 - Accepted 17 March 1982)

\begin{abstract}
1. Digesta passage and retention were measured in heifers, sheep, goats, equines and rabbits of varying body-weights when given timothy (Phleum pratense) hay.

2. Two passage markers were compared, cobalt (III) ethylene diamine tetraacetate (CoEDTA) and chromiummordanted timothy fibre for liquid and solid phase respectively. Both markers were injected into the rumen of the ruminants and into the caecum of the equines and rabbits.

3. In ruminants, two different sets of rate constants $\left(k_{1}\right.$ and $\left.k_{2}\right)$ were derived from a two-pool model for marker passage, using a graphical approach and a computer-based non-linear least-squares curve-fitting technique.

4. Retention times, due to unidirectional flow through the gastrointestinal tract (transit time) and due to pool effects (mean retention time, MRT), were calculated.

5. Curve fitting was only successful for the excretion of liquids in ruminants. The two-pool model was not applicable to the passage of solids.

6. Apparent retention of liquid was always shorter than for solids in all species, except in rabbits. However, absorption of CoEDTA was too large in the rabbits to determine liquid retention accurately. Times for first appearance of the two markers were similar within animal groups.

7. MRT values were lowest in the rabbit, intermediate in equines and high in the ruminants. The MRT values (h) of solids and liquid respectively were: large heifers 65,18 ; small heifers 48,20 ; goats 41 , 28; sheep 57, 26; equines 23,18 ; rabbits $5 \cdot 3$, not determined.

8. Liquid retention seemed to decrease somewhat with increasing body-weight in the ruminants. Solids retention decreased with decreasing body-weight in the ruminants, but sheep had longer retention times than goats of similar size. Equines exhibited large individual variation in retention of the liquid or solid markers, seemingly unrelated to size. No effect of size was seen in the retention of solids in the rabbits.
\end{abstract}

Digesta rate of passage in the herbivore is of great importance to the nutrition and feeding strategy of the animal. There is reason to believe that the small herbivore will have a more rapid rate of passage than the large herbivore, due to a higher food intake relative to body-weight and gut volume (Parra, 1978). It appears that the ruminant gut architecture imposes more restrictions to the passage of digesta than is found in the non-ruminant herbivore, affecting the relative ability of the ruminant to consume large quantities of fibrous feeds.

A previous paper (Udén \& Van Soest, 1982) reported the digestive efficiencies of ruminants, equines and rabbits to utilize the fibre components of timothy (Phleum pratense) hay.

The objectives of these experiments were to: (a) study the effects of gut architecture and body size on the retention of digesta (liquid and solid), (b) compare the retention and passage of liquids and solids and $(c)$ compare different techniques for calculating the rate of passage and retention times.

\section{EXPERIMENTAL}

\section{Animals, housing and feeding}

The animals used were identical to those in a previous experiment (Udén \& Van Soest, 1982) and consisted of five heifers, three goats, four sheep, four ponies, two horses and four

* Present address: Department of Animal Science, Swedish University of Agricultural Sciences, S-750 07 Uppsala, Sweden. 
rabbits. Housing and feeding was also the same and samples were obtained simultaneously in the two experiments.

\section{Markers}

Two different markers were administered through cannulas; chromium-mordanted timothy fibre and cobalt (III) ethylene diamine tetraacetate (CoEDTA) (Udén et al. 1980). The origin of the timothy fibre used for the mordanting was: heifers, rumen contents from dorsal sac; equines, faeces from one pony; sheep and goats, hay ground to pass a $6 \mathrm{~mm}$ screen giving a particle size similar to that seen in the rumen when given long hay; rabbits, caecal contents from other rabbits given the same diet.

Chromium was mordanted to timothy fibre at a level of $60 \mathrm{~g} / \mathrm{kg}$ dry matter (DM) and prepared according to Udén et al. (1980).

The rabbits were dosed with radioactive ${ }^{51} \mathrm{Cr}$-mordanted cell walls prepared by neutron activation of cold Cr-mordanted cell walls. CoEDTA was synthesized as the lithium or sodium salt; the former having a molecular weight of 408 and with similar chemical and physical properties to CrEDTA (Udén et al. 1980).

Dosing schedule, body-weights and amount of marker given are shown in Table 1. CoEDTA was dissolved in water before dosing, whereas the Cr-mordanted cell walls were administered dry. No special care was taken to ensure an immediate, uniform mixture of the marker and the digesta.

\section{Sampling of faeces}

Faecal samples were collected day and night at intervals shown in Table 2. Sample size varied from 1 to $15 \mathrm{~g}$ DM, depending on species (Table 1). Total length of time of the collection periods are also given in Table 2.

\section{Analysis of $\mathrm{Co}$}

The faecal samples were dried, weighed and water was added equal to $10 \mathrm{ml} / \mathrm{g}$ DM and allowed to stand for $4-5 \mathrm{~d}$ (evaporation prevented) with vigorous shaking each day. To concentrate the $\mathrm{Co}$ in the liquid phase, $25 \%$ of the liquid was transferred to a beaker, evaporated, ashed at $550^{\circ}$, wetted with $4 \mathrm{M}$-hydrochloric acid, evaporated again and taken up in saturated ammonium EDTA $\left(\mathrm{NH}_{4} \mathrm{EDTA}\right)(40 \%$ of the original volume). The reaction (formation of the CoEDTA chelate) required at least $24 \mathrm{~h}$ at room temperature. An atomic absorbtion spectrophotometer (Perkin Elmer model 305 B) was used to determine the Co concentration in the samples. The amount of Co in the faeces was expressed as $\mu \mathrm{g} / \mathrm{g} \mathrm{DM}$, adjusted for background levels of the element.

\section{Analysis of $\mathrm{Cr}$}

$\mathrm{Cr}$ was analysed by means of neutron activation in the faeces of ruminants and equines. Wet faecal samples were first soaked in a neutral detergent and saturated $\mathrm{NH}_{4} \mathrm{EDTA}$ solution mixture $(50: 50, \mathrm{v} / \mathrm{v})$ at $\mathrm{pH} 7(10 \mathrm{ml}$ solution/g DM). After soaking, the samples were filtered, washed, dried, ashed and activated in a TRIGA Mark II reactor, which had a neutron flux of $5 \times 10^{13}$ neutrons $/ \mathrm{mm}^{2}$ per s. Analysis of the gamma spectrum was done after approximately 3 weeks of cooling off, using a well-type sodium iodide crystal detector or an approximately $70 \mathrm{~mm}$ flat germanium-lithium detector and a multichannel analyser with memory and printout units.

Rabbit faeces were divided up into hard and soft faeces and analysed separately. The radioactive ${ }^{51} \mathrm{Cr}$ in the faeces was analysed, using the same equipment for counting as that described previously. No preparation of the samples was necessary, other than drying. 
Table 1. Mean body-weight, cell wall intake, amount of marker given, faecal sample sizes and time of dosing

\begin{tabular}{|c|c|c|c|c|c|c|c|}
\hline \multirow[b]{2}{*}{ Animal } & \multirow{2}{*}{$\begin{array}{l}\text { No. of } \\
\text { animals }\end{array}$} & \multirow{2}{*}{$\begin{array}{c}\text { Mean } \\
\text { body-wt } \\
(\mathrm{kg})\end{array}$} & \multirow{2}{*}{$\begin{array}{l}\text { Cell wall } \\
\text { intake }(\mathrm{g} / \mathrm{kg} \\
\text { body-wt) }\end{array}$} & \multirow{2}{*}{$\begin{array}{l}\text { Time of } \\
\text { day of } \\
\text { dosing }(h)\end{array}$} & \multicolumn{2}{|c|}{ Amount of marker (g) } & \multirow{2}{*}{$\begin{array}{l}\text { Faecal sample } \\
\text { size ( } \mathrm{g} \text { DM) }\end{array}$} \\
\hline & & & & & $\mathrm{Cr}$ & CoEDTA & \\
\hline Large heifers & 3 & 560 & 10 & 20.00 & 0.6 & 55 & 15 \\
\hline Small heifers & 2 & 240 & 9 & 09.00 & 5 & 15 & 10 \\
\hline Goats & 3 & 29 & 16 & 24.00 & 2 & 5 & 3 \\
\hline Sheep & 4 & 30 & 15 & 24.00 & 2 & 5 & 3 \\
\hline Equines & 6 & 217 & 13 & 10.00 & $1-5$ & $2 \cdot 5-20$ & 10 \\
\hline Rabbits & 4 & $3 \cdot 2$ & 18 & 18.00 & $80000^{*}$ & 0.25 & 1 \\
\hline
\end{tabular}

${ }^{*}$ Counts $/ \mathrm{min}$ for ${ }^{51} \mathrm{Cr}$.

Table 2. Sampling of faeces in the different animal groups: intervals between two samplings in different periods after a single dose of marker

\begin{tabular}{cccccc}
\hline & \multicolumn{5}{c}{ Sampling intervals (h) } \\
\cline { 2 - 6 } $\begin{array}{c}\text { Period after } \\
\text { dosing (h) }\end{array}$ & Large heifers & Small heifers & Sheep-goats & Equines & Rabbits \\
\hline $0-8$ & - & - & - & - & 2 \\
$8-12$ & 4 & 4 & 2 & 4 & 2 \\
$12-24$ & 4 & 4 & 2 & 4 & 4 \\
$24-48$ & 4 & 4 & 4 & 4 & 8 \\
$48-72$ & 8 & 8 & 4 & 8 & 12 \\
$72-108$ & 8 & 8 & 8 & 8 & - \\
$108-140$ & 12 & - & 12 & - & - \\
\hline
\end{tabular}

\section{Calculation of rate constants and retention times}

Rate constants for the passage of markers were calculated in the ruminants, assuming a two-pool model with irreversible flows (Grovum \& Williams, 1973). Two curve-fitting methods were used; one graphical, curve peeling technique (Resigno \& Segre, 1966) and one computer-based non-linear least-squares alogarithm (Dennis et al. 1977). The fitting was done on the average curves for each group. Individual curves were only analysed using the graphical procedure. Average curves were constructed after normalizing heights of individual excretion curves. In the graphical method the faecal curves of marker concentrations were plotted on semi-log paper and divided up in linear and non-linear portions by eye.

When using the computer program all values were fitted simultaneously to the twoexponential function of the passage model (Grovum \& Williams, 1973). The mean squared error (MSE) was derived as:

$$
\operatorname{MSE}=\sum_{i=1}^{n}\left[\frac{c_{i}-y_{i}}{c_{i}}\right]^{2}:(n-p)
$$

where $c_{i}$ is the calculated value for faecal marker concentration, $y_{i}$ is the observed value for faecal marker concentration, $n$ is the number of observations and $p$ is the number of parameters estimated (equal to 3). The lag-time of the function (time when the function value is zero) was fixed at the time of the first appearance of the marker minus $1 \mathrm{~h}$.

A mean retention time (MRT) of each marker in the gastrointestinal tract (GIT) due to 
pool effects was calculated in all the animals, as the weighted MRT:

$$
\text { MRT }=\sum_{i=1}^{n} \frac{\left(y \cdot t_{i}\right)}{y_{i}}-T T,
$$

where $y$ is the amount of marker voided between two samplings (units of marker), $t_{i}$ is the mean time (h) for sampling and $T T$ is the transit time equal to the time (h) of first appearance of the marker. Equation (2) is essentially the same as the one used by Blaxter et al. (1956). $T T$ was substracted in order to eliminate retention time as a result of undirectional flow through the GIT.

In rabbits, the amounts of ${ }^{51} \mathrm{Cr}$ marker per sampling interval was determined whereas, in ruminants and equines, only faecal marker concentrations were recorded. As a substitute for marker quantities, faecal marker concentration multiplied by the length of the sampling interval was used in ruminants and equines.

After the experiments were concluded, it was discovered that the sampling periods for $\mathrm{Cr}$ in large and small heifers were too short and that a considerable amount of marker was still in the animals. This would have resulted in an underestimation of MRT. To correct this, the linear portion of the semi-logarithmic plots of $\mathrm{Cr}$ excretion were extrapolated to a value equal to 0.01 of maximum. The extrapolated portion of the curves was divided up in intervals of $12 \mathrm{~h}$ for the calculation of MRT.

\section{RESULTS}

Figure $1(a-d)$ shows average and Fig. $1(e-f)$ and Fig. 2 show individual faecal marker excretion curves for the different species. The ruminant excretion curves were generally smoother than those from equines and rabbits, indicating more continuous digesta flow. Table 3 shows the results from calculating rate constants by the two different techniques.

The effects of marker, species and body size on passage and retention are shown in Table 4.

\section{Comparison of methods to calculate rate of passage in ruminants}

The graphical and computer methods gave similar $k_{1}$ (descending portion of curve) and $k_{2}$ (ascending portion of curve) rate constants only when applied to the CoEDTA excretion curves.

Average values for all ruminant groups and correlations between the two methods are listed in Table 3.

The poorest correlation was found for the $\mathrm{Cr}-k_{2}$ values.

It was obvious that the two-pool model could not be fitted adequately to the $\mathrm{Cr}$ curves using any of the two methods employed. Undershoot - overshoot patterns were apparent in all instances. In Table 4, only the $k_{1}$ values from the graphical procedure are listed.

\section{Comparison of the liquid and solid markers}

In both the ruminants and equines, Co-MRT was shorter than for Cr-MRT (Table 4). The Cr-MRT:Co-MRT was highest in the large heifers (3.6) and lowest in the equines $(1 \cdot 3)$.

Apparent retention of liquid in the rabbit was approximately thirty times longer than for solids. Urinary excretion of CoEDTA was of the order of $25 \%$ during a 6 -d collection period. The large absorption of liquid from the gut was believed to cause a reduction in the MRT values observed. No absolute values are therefore reported here on the retention of liquid in the rabbit.

In Table 4, times for first appearance (transit time) are shown. No major differences were seen between the markers. 

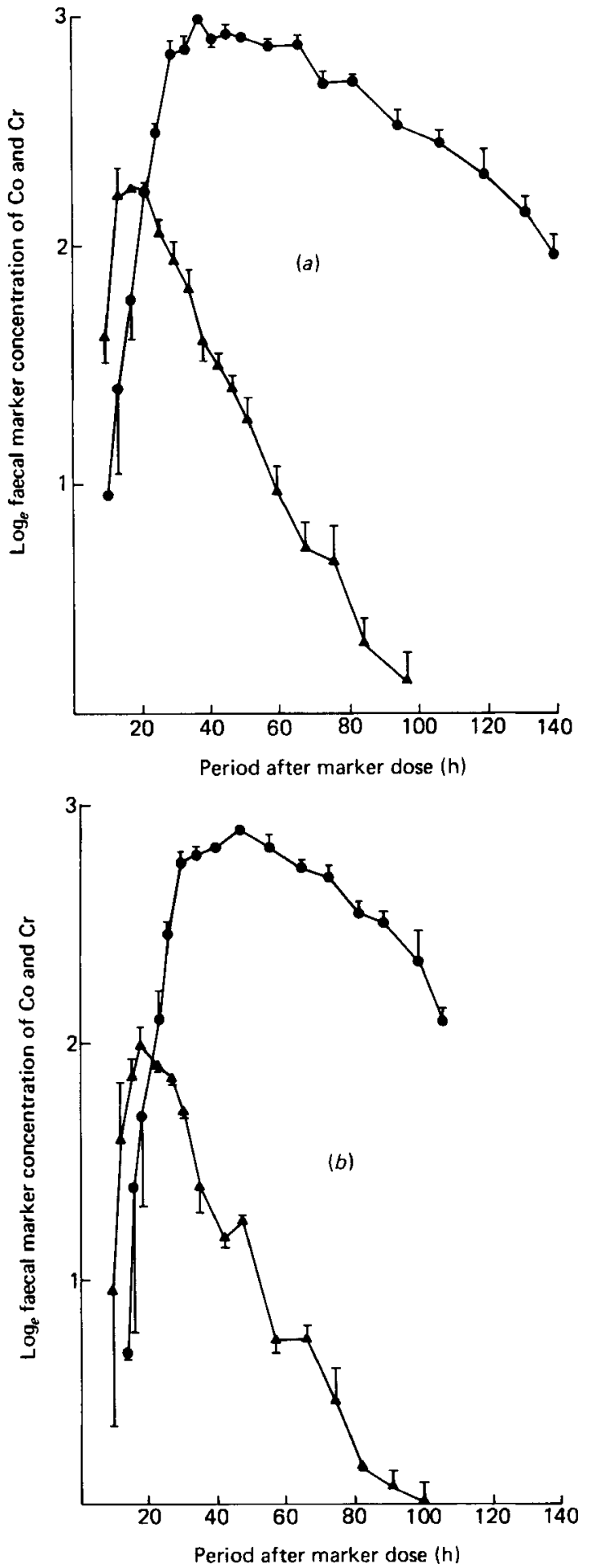

Fig. 1. Average faecal excretion curves and standard errors from $(a)$ large heifers, $(b)$ small heifers, $(c)$ goats, $(d)$ sheep and $(e)$ and $(f)$ individual faecal excretion curves from two horses. CoEDTA $(\boldsymbol{A})$ and Cr-mordanted timonthy (Phleum pratense) cell walls $(\Theta)$ were given as a single dose in the rumen (ruminants) or caecum (horses). 

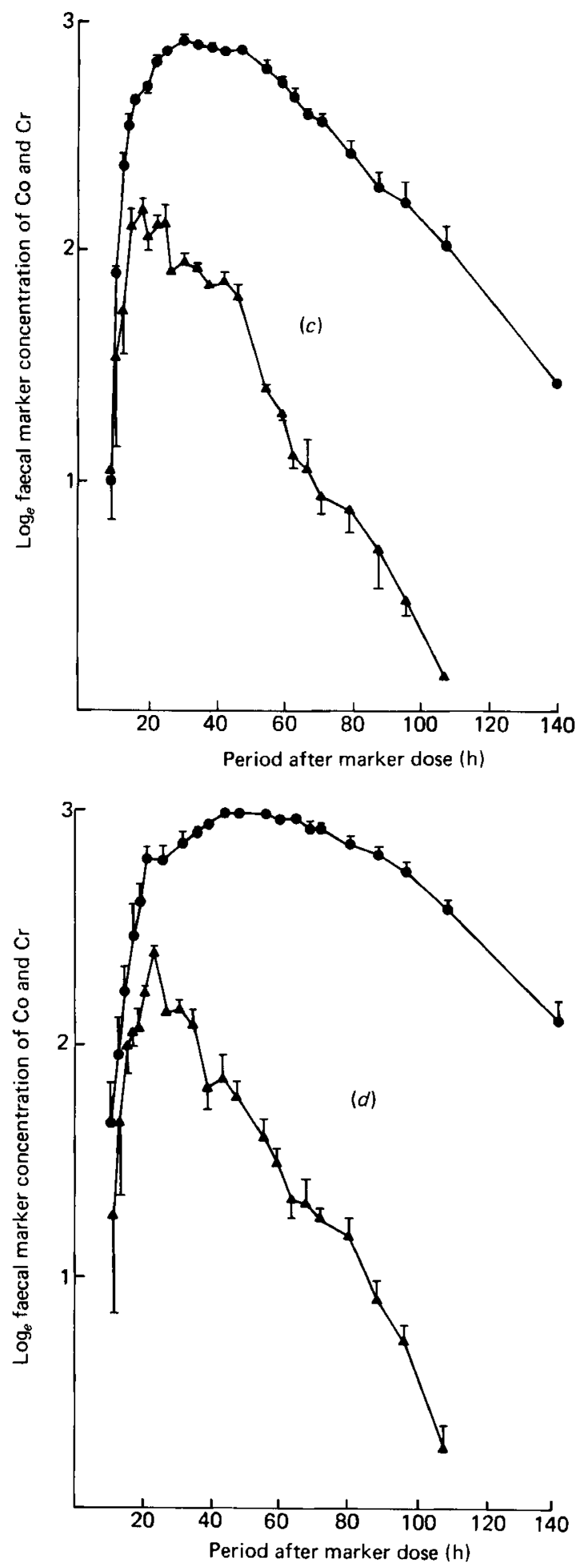

Fig. 1,-cont. 
Digesta passage in herbivores
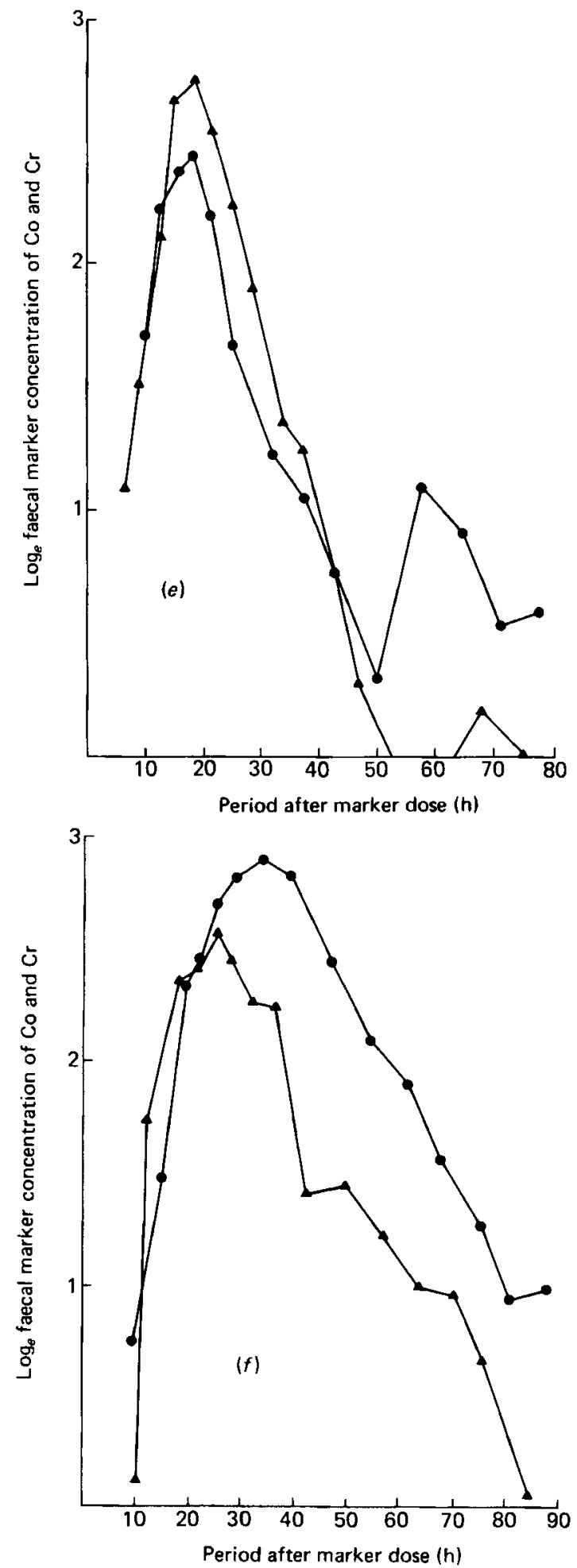

Fig. 1.-cont. 


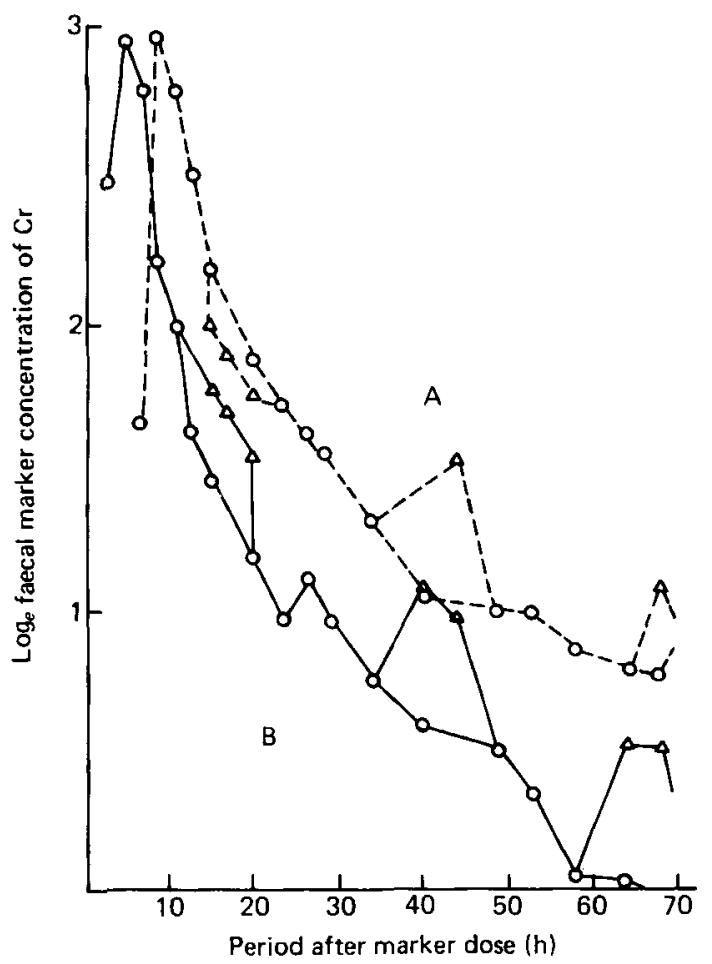

Fig. 2. Faecal marker excretion after a single dose of $\mathrm{Cr}$-mordanted timothy (Phleum pratense) cell walls into the caecum of rabbits $\mathrm{A}(---)$ and $\mathrm{B}(-)$ fitted with neck collars. Cr concentrations in hard (O) and soft $(\triangle)$ faeces shown separately.

Table 3. Rate constants $\left(\mathrm{k}_{1}\right.$ and $\left.\mathrm{k}_{2}\right)$ and associated standard deviations: Means of ruminant group averages, ottained by graphical or computer methods

\begin{tabular}{|c|c|c|c|c|c|c|c|c|}
\hline & \multicolumn{4}{|c|}{ CoEDTA } & \multicolumn{4}{|c|}{$\mathrm{Cr}$} \\
\hline & \multicolumn{2}{|c|}{$k_{1}$} & \multicolumn{2}{|c|}{$k_{2}$} & \multicolumn{2}{|c|}{$k_{1}$} & \multicolumn{2}{|r|}{$k_{2}$} \\
\hline & Mean & SE & Mean & $\mathbf{S E}$ & Mean & $\mathbf{S E}$ & Mean & SE \\
\hline $\begin{array}{l}\text { Graphical } \\
\text { method }\end{array}$ & 0.058 & $( \pm 0.007)$ & 0.29 & $( \pm 0 \cdot 19)$ & 0.028 & $( \pm 0.005)$ & 0.065 & $( \pm 0 \cdot 009)$ \\
\hline $\begin{array}{l}\text { Computer } \\
\text { method }\end{array}$ & 0.059 & $( \pm 0.004)$ & 0.22 & $( \pm 0 \cdot 12)$ & 0.026 & $( \pm 0.008)$ & 0.046 & $( \pm 0.007)$ \\
\hline Correlation & 0.988 & & 0.943 & & 0.950 & & 0.849 & \\
\hline
\end{tabular}

The effect of species and body size

Co-MRT values varied considerably among species. Large heifers had the longest MRT, but the sheep exhibited a remarkably long MRT for their size. Goats had a considerably shorter MRT, as compared to sheep. The differences could not be explained by discrepancies in body-weights or intakes.

Equines had a Cr-MRT, which was much shorter than that for any of the ruminants. The individual variation in MRT of this group and the shape of the excretion curves were also remarkable and seemed to be totally unrelated to body size (Fig. $1(e)$ and $(f)$ ). 
Table 4. Mean retention time, transit time and rate of passage for CoEDTA and chromiummordanted timothy (Phleum pratense) cell walls in the gastrointestinal tract of ruminants, equines and rabbits. Markers were administered in the rumen (ruminants) or in the caecum (equines and rabbits). Rate constants were calculated using the graphical technique

\begin{tabular}{|c|c|c|c|c|c|c|c|}
\hline \multirow[b]{2}{*}{ Animal } & \multirow[b]{2}{*}{$\begin{array}{l}\text { Animal body- } \\
\text { wt (kg) }\end{array}$} & \multicolumn{3}{|c|}{$\mathrm{Cr}$} & \multicolumn{3}{|c|}{ CoEDTA } \\
\hline & & $\begin{array}{c}k_{1} \\
(1 / \mathrm{h})\end{array}$ & $\begin{array}{c}\text { MRT } \dagger \\
\text { (h) }\end{array}$ & $\underset{\text { (h) }}{T T \ddagger}$ & $\begin{array}{c}k_{1} \\
(1 / h)\end{array}$ & $\begin{array}{c}\text { MRT } \\
\text { (h) }\end{array}$ & $\begin{array}{l}T T \\
\text { (h) }\end{array}$ \\
\hline $\begin{array}{l}\text { Large } \\
\text { heifers }\end{array}$ & $\begin{array}{l}\text { A } 610 \\
\text { B } 610 \\
\text { C } 450\end{array}$ & $\begin{array}{l}0 \cdot 027 \\
0 \cdot 020 \\
0 \cdot 018\end{array}$ & $\begin{array}{l}57 \\
66 \\
74\end{array}$ & $\begin{array}{l}12 \\
16 \\
12\end{array}$ & $\begin{array}{l}0.074 \\
0.064 \\
0.061\end{array}$ & $\begin{array}{l}15 \\
20 \\
20\end{array}$ & $\begin{array}{l}10 \\
10 \\
10\end{array}$ \\
\hline Mean & & 0.022 & 65 & 13 & 0.066 & 18 & 10 \\
\hline $\begin{array}{l}\text { Small } \\
\text { heifers }\end{array}$ & $\begin{array}{l}\text { A } 220 \\
\text { B } 260\end{array}$ & $\begin{array}{l}0.022 \\
0.032\end{array}$ & $\begin{array}{l}55 \\
40\end{array}$ & $\begin{array}{l}14 \\
14\end{array}$ & $\begin{array}{l}0.063 \\
0.061\end{array}$ & $\begin{array}{l}20 \\
19\end{array}$ & $\begin{array}{l}10 \\
10\end{array}$ \\
\hline Mean & & 0.027 & $+\quad 48$ & 14 & 0.062 & 20 & 10 \\
\hline Goats & $\begin{array}{l}\text { A } 32 \\
\text { B } 24 \\
\text { C } 30\end{array}$ & $\begin{array}{l}0.043 \\
0.042 \\
0.028\end{array}$ & $\begin{array}{l}40 \\
36 \\
46\end{array}$ & $\begin{array}{l}10 \\
12 \\
10\end{array}$ & $\begin{array}{l}0.052 \\
0.051 \\
0.055\end{array}$ & $\begin{array}{l}30 \\
23 \\
29\end{array}$ & $\begin{array}{l}10 \\
12 \\
11\end{array}$ \\
\hline Mean & & 0.038 & 41 & 11 & 0.053 & 28 & 11 \\
\hline Sheep & $\begin{array}{l}\text { A } 33 \\
\text { B } 25 \\
\text { C } 34 \\
\text { D } 31\end{array}$ & $\begin{array}{l}0.027 \\
0.021 \\
0.021 \\
0.037\end{array}$ & $\begin{array}{l}64 \\
66 \\
48 \\
51\end{array}$ & $\begin{array}{l}14 \\
12 \\
12 \\
12\end{array}$ & $\begin{array}{l}0.053 \\
0.048 \\
0.057 \\
0.052\end{array}$ & $\begin{array}{l}28 \\
28 \\
22 \\
26\end{array}$ & $\begin{array}{l}11 \\
13 \\
12 \\
10\end{array}$ \\
\hline Mean & & 0.027 & 57 & 13 & 0.053 & 26 & 12 \\
\hline Equines & $\begin{array}{l}\text { A } 95 \\
\text { B } 117 \\
\text { C } 145 \\
\text { D } 172 \\
\text { E } 275 \\
\text { F } 500\end{array}$ & & $\begin{array}{l}28 \\
32 \\
25 \\
14 \\
24 \\
17\end{array}$ & $\begin{array}{r}7 \\
9 \\
11 \\
11 \\
9 \\
7\end{array}$ & & $\begin{array}{l}21 \\
23 \\
16 \\
13 \\
20 \\
14\end{array}$ & $\begin{array}{r}8 \\
13 \\
13 \\
10 \\
13 \\
10\end{array}$ \\
\hline Mean & & & 23 & 9 & & 18 & 11 \\
\hline $\begin{array}{l}\text { Rabbits } \\
\text { Flemish } \\
\text { gigants } \\
\text { Dutch } \\
\text { belted } \\
\text { Mean }\end{array}$ & $\begin{array}{l}\text { A } 5.4 \\
\text { B } 4.8 \\
\text { C } 1.3 \\
\text { D } 1.3\end{array}$ & & $\begin{array}{l}5 \cdot 1 \\
6 \cdot 5 \\
4 \cdot 2 \\
5 \cdot 4 \\
5 \cdot 3\end{array}$ & $\begin{array}{l}3 \\
7 \\
3 \\
3 \\
4\end{array}$ & & & \\
\hline
\end{tabular}

* $k_{1}$, Rate constant of passage (slope of descending portion of excretion curve).

$\dagger$ MRT, mean retention time (transit time excluded).

$\ddagger T T$, transit time (time of first appearance of marker).

Rabbits had extremely short lower tract retention of $\mathrm{Cr}$, apparently a result of small lower tract DM contents, being approximately $0.5 \%$ of body-weight compared to approximately $2 \%$ in the forestomach of a ruminant (Udén, 1978). No effect of body size was detected in the retention of solids in this group.

Retention of liquid in ruminants seemed to be longer in sheep and goats than in cattle, contrary to the retention of solids. 


\section{DISCUSSION}

One dominating pool was evident in all ruminant excretion curves, judging from the terminal linear portion of the curves. For $\mathrm{Cr}$ this pool probably consists of particles with improved capability for passage, due to particle size reduction and hydration. The physical control and mathematical description of these events are little understood.

Attempts to fit the ruminant $\mathrm{Cr}$ values to a two-pool model, consisting of a large rumen pool and a small lower tract pool, were not successful. The computer program was unbiased and fitted all values simultaneously, resulting in a poor fit with overshoot - undershoot patterns. The graphical procedure fitted the linear and non-linear portions of the curve in two steps, which gave a very poor fit of early values. Other models with three pools (Milne et al. 1978) or time dependent rates (Ellis et al. 1979) should have resulted in better fits. These models were not tried, however, as no physical identification of extra pools and time-dependent rates seemed possible at the time. More critical experiments are needed to clarify the chromium excretion curves in ruminants.

Comparing the passage and retention of liquids and solids indicated less selective retention of solids in the equine lower tract than in the forestomach of the ruminants. It was also evident that there was an almost complete absence of a mixing pool of liquids in the ruminant lower tract, judging from the shortage of values to calculate $k_{2}$ for CoEDTA. In the case of solids, the presence or absence of a lower tract mixing pool could not be established. Solids $k_{1}$ varied more within groups than liquid $k_{1}$. Anatomical and physiological differences between animals within groups seem to have a relatively greater effect on the slowest moving fraction than on the fastest. This could be analogous to the results of Colucci (1979) showing less relative individual variation at high intake (rapid digesta passage) than at low intake (slow digesta passage).

The disadvantage of using only MRT as a measure of digesta turnover in the digestive tract, is that more or less complete marker recoveries are required if extrapolations are to be avoided. The other drawback is that values obtained by this method can tell us nothing of the passage between compartments.

Values in the literature for MRT vary considerably within species. Level of feeding, body size, type of diet and its physical form and the choice of marker are probable causes of variation. Sheep have been studied most extensively among the ruminants. The values found in the literature for liquid retention time due to pool effects of the sheep rumen $(6-20 \mathrm{~h})$ (Hecker, 1971; Potter et al. 1972; Grovum \& Williams, 1973; Egan et al. 1975), corresponding to our $1 / k_{1}$ values, compare well with those found in the present study of 18-21 h.

The approximate value of $60 \mathrm{~h}$ for MRT of solids in the sheep was high when compared with literature values of $30-60 \mathrm{~h}$ for hay-fed animals (Blaxter et al. 1956; Francois \& Compère, 1971; Grovum \& Williams, 1973).

Vander Noot et al. (1967) and Wolter et al. (1974) report a 13-26 h pool retention time of solids in the GIT of equines and from the values of Argenzio et al. (1974) a value of $70 \mathrm{~h}$ can be calculated for liquid retention in the lower tract. The value of $18 \mathrm{~h}$ for CoEDTA, found here, differs considerably from that of Argenzio et al. (1974), whereas the Cr retention of $23 \mathrm{~h}$ compares well with the reported values for solid retention.

The few values found in rabbits given non-purified diets, indicate a very short MRT for solids. Values of 6-12 h have been reported by Hoover \& Heitman (1972) and Brandt \& Thacker (1958). The corresponding value in our study was $9 \mathrm{~h}$ for $\mathrm{Cr}$ in the lower tract, including transit time.

In a previous study (Udén \& Van Soest, 1982), fibre digestibilities were reported for timothy hay, fed to the same animals as in the present experiment. Fibre digestibilities were 


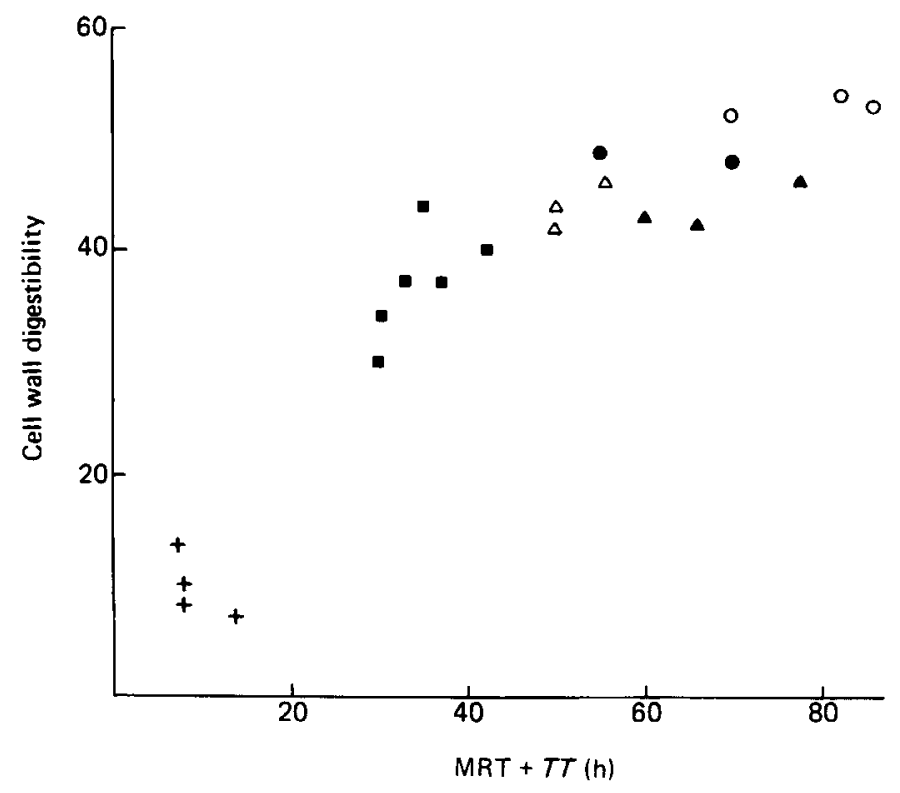

Fig. 3. Relationship between cell wall digestibility and total time available for digestion in the gastrointestinal tract (MRT $+T T$ ) of various species: $(O)$, large heifers; $(\Theta)$, small heifers; $(\Delta)$, goats; $(\boldsymbol{A})$, sheep; ( $\mathbf{C})$, equines; and $(+)$, rabbits.

positively correlated with the MRT values when all groups were combined, but within groups or species there were considerable variations (Fig. 3). Sheep had, for example, comparatively lower digestibility in relation to MRT than the other ruminants.

\section{REFERENCES}

Argenzio, R. A., Lowe, J. E., Pickard, D. W. \& Stevens, C. E. (1974). Am. J. Physiol. $288,454$.

Blaxter, K. L., Graham, N. Mc. \& Waiman, F. W. (1956). Br. J. Nutr. 10, 69.

Brandt, C. S. \& Thacker, E. J. (1958). J. Anim. Sci. 17, 218.

Colucci, P. E. (1979). Rate of passage of digesta through the gastro-intestinal tract in dairy cattle. MS thesis, Cornell University, Ithaca, NY.

Dennis, J. E. Jr, Gay, D. M. \& Welsch, R. E. (1977). NBER Working Paper. Series no. 196. Ithaca, NY: Department of Computer Science, Cornell University.

Egan, E. R., Walker, D. J., Nader, C. J. \& Storrer, G. (1975). Aust. J. agric. Res. $26,909$.

Ellis, W. C., Matis, J. H. \& Lascano, C. (1979). Fedn Proc. Fedn Am. Socs exp. Biol. 38, 2702.

Francois, E. \& Compère, R. (1971). Bull. Rech. Agron. Gembloux, 6, 43.

Grovum, W. L. \& Williams, V. J. (1973). Br. J. Nutr. 30, 313.

Hecker, J. F. (1971). J. agric. Sci., Camb. 77, 151.

Hoover, W. H. \& Heitman, R. N. (1972). J. Nutr. 102, 375.

Milne, J. A., Macrae, J. C., Spence, Angela M. \& Wilson, S. (1978). Br. J. Nutr. 40, 347.

Parra, R. (1978). In The Ecology of Arboreal Folivores [G. G. Montgomery, editor]. Washington DC: Smithsonian Institution Press.

Potter, B. J., Walker, D. J. \& Forrest, W. W. (1972). Br. J. Nutr. 25, 75.

Resigno, A. \& Segre, G. (1966). Drug and Tracer Kinetics [P. R. Gross, editor]. Waltham, Mass: Blaisedell Publishing Co.

Snedecor, G. W. \& Cochran, W. G. (1973). Statisticul Methods, 6th ed. Ames, Iowa: Iowa State University Press. Udén, P. (1978). Comparative studies on rate of passage, particle size and rate of digestion in ruminants, equines, rabbits and man. PhD thesis, Cornell University, Ithaca. NY.

Udén, P., Colucci, P. E. \& Van Soest, P. J. (1980). J. Sci. Fd Agric. 31, 625.

Udén, P. \& Van Soest, P. J. (1982). Br. J. Nutr. 47, 267.

Vander Noot, G. W., Symons, L. D., Lydman, R. K. \& Fonnesbeck, P. V. (1967). J. Anim. Sci. 26, 1309.

Wolter, R. A., Durix, A. \& Letourneau, J.-C. (1974). Annls. Zootech. 23, 294. 